\title{
25. VARIABILITY IN SEA-SURFACE CONDITIONS IN THE NORTH ATLANTIC-ARCTIC GATEWAYS DURING THE LAST 140,000 YEARS ${ }^{1}$
}

\author{
J.F. McManus, ${ }^{2}$ C.O. Major, ${ }^{2}$ B.P. Flower, ${ }^{3}$ and T. Fronval ${ }^{4}$
}

\begin{abstract}
Three sites from Leg 151 were selected for a study of orbital- and millennial-scale climate variability during the last 140,000 years. This interval, from marine isotope Stage (MIS) 6 to the present, includes the last large climate cycle of the Quaternary. Sites 907,909 , and 910 constitute a transect, roughly north-south, from the Iceland Plateau, through the Fram Strait, to the Yermak Plateau. Sediment cores from these sites were analyzed for the abundance and diversity of planktonic foraminifers and the quantity and composition of ice-rafted debris (IRD).

Leg 151 drilling was successful in recovering young sediments. This is best demonstrated in Hole $907 \mathrm{~A}$, which has a sedimentation rate of $1.7 \mathrm{~cm} / \mathrm{k} . \mathrm{y}$, where an 11,000-year-old volcanic ash is disseminated at a depth of 0.2 meters below seafloor (mbsf), indicating good recovery of the overlying Holocene section.

The last climate cycle in Hole 907A is well defined by faunal assemblages and abundances, which indicate that mild conditions were limited to peak interglacials. Ice-rafted debris is abundant at all other times, although discrete peaks in the ratio of ice-rafted grains to foraminifers, perhaps analogous to the Heinrich events of the North Atlantic, occur only during MIS 2-4 and 6. Site 909 in the Fram Strait has a sedimentation rate of $3.4 \mathrm{~cm} / \mathrm{k}$.y., and is characterized by variability in the abundance of ice-rafted debris and clastic rock fragments. Sharp increases in the weight percentage of coarse sediment and the occurrence of detrital coal mark MIS 6, and contrast with the last (MIS 2) glaciation. Site 910 on the Yermak Plateau has a sedimentation rate of $2.7 \mathrm{~cm} / \mathrm{k} . \mathrm{y}$., and is dominated by detrital sediments. The abundance of coarse sediment remains high with little variation throughout the study interval. Ice-rafted clastic rock fragments are relatively less important on the Yermak Plateau than in the Fram Strait, implying different glacial source areas. The similarity between the last two glacial and interglacial pairs seen on the Iceland Plateau (as in the subpolar North Atlantic) is less evident in our high latitude cores.
\end{abstract}

\section{INTRODUCTION}

Sites drilled during Ocean Drilling Program Leg 151 are well situated for studies of the history of climate, ocean circulation, ice-rafting, and sea ice in the North Atlantic-Arctic Gateways region (Fig. 1). Studies from widespread other locations have demonstrated the generally cyclical nature of Quaternary climate, with conditions varying from glacial to interglacial through transitions that may be gradual or abrupt (e.g., Hays et al., 1976; Imbrie et al., 1984). Higher frequency cycles and episodic behavior are increasingly evident during the last climate cycle (e.g., Dansgaard et al., 1971; Heinrich, 1988; Bond et al., 1993; Fronval et al., 1995) and may also typify earlier intervals. The relatively thick Quaternary sections that were recovered during Leg 151 hold the potential for high resolution studies of variability down to millennial time scales. We sought in this study to examine the extent to which the last large climate cycle of the Quaternary was recovered during Leg 151 , to assess the variability of conditions throughout that interval, and to consider similarities and contrasts between the youngest successive glaciations and interglacials, for comparison with older intervals.

We focused on sedimentary particles greater than $150 \mu \mathrm{m}$. Such coarse sediment, consisting in this study of calcite foraminifer tests and a variety of detrital sand grains, is most likely to be deposited ver-

'Thiede, J., Myhre, A.M., Firth, J.V., Johnson, G.L., and Ruddiman, W.F. (Eds.), 1996. Proc. ODP, Sci. Results, 151: College Station, TX (Ocean Drilling Program).

2Lamont-Doherty Earth Observatory, Palisades, NY 10964, U.S.A. McManus: jmc@lamont.ldeo.columbia.edu

${ }^{3}$ Earth Sciences Board, University of California, Santa Cruz, CA 95064, U.S.A

${ }^{4}$ Geologisk Institute, University of Bergen, Allégaten 41, N-5007, Bergen, Norway. Present address: Department of Geology, University of Copenhagen, Ostervoldgade 10 , DK-1350 Copenhagen K, Denmark. tically and least likely to be reworked, and thus provides a link to the surface waters overlying the sites. The grains are also abundant enough (typically on the order of thousands per sample) to provide good statistics for particle counts. Sedimentary foraminifer abundances and assemblages reflect the severity of climatic conditions at the overlying sea surface, while the amount and type of coarse detrital sediment delivered by icebergs may provide clues to the location and extent of nearby ice sheets. Previous studies have successfully utilized both faunal assemblages and ice-rafted debris (IRD) to reconstruct surface water trajectories and water mass migrations (e.g., Ruddiman and McIntyre, 1976; Ruddiman, 1977; Kellogg, 1980; Bischof, 1990; Spielhagen, 1991; Baumann et al., 1995).

\section{METHODS}

A series of samples was removed every $5 \mathrm{~cm}$ from the working half of the split core, beginning at $0.02 \mathrm{mbsf}$ and continuing through all sections of the first two cores at each site. The samples were taken using a cylindrical $5-\mathrm{cm}^{3}$ tube, which yielded 2-3 grams of sediment after drying. The sediment plugs were freeze-dried, weighed, and wet sieved into coarse $(>63 \mu \mathrm{m})$ and fine size fractions. An additional size fraction was separated by dry sieving through a $150-\mu \mathrm{m}$ screen for counting and identification. This fraction, consisting of adult foraminifer tests, mineral grains, and rock fragments, was split to provide counts of approximately 300 foraminifer or lithic grains. The particles were scattered in a gridded counting tray and visually inspected through a binocular microscope at 25 to 50 magnification. Counts and identifications were performed on each sample, beginning from the core top down to a level within MIS 6. The oxygen isotope stratigraphy was established by measurements from these same sites (Flower, this volume; Fronval and Jansen, this volume) and by correlation with published records from nearby sites. 


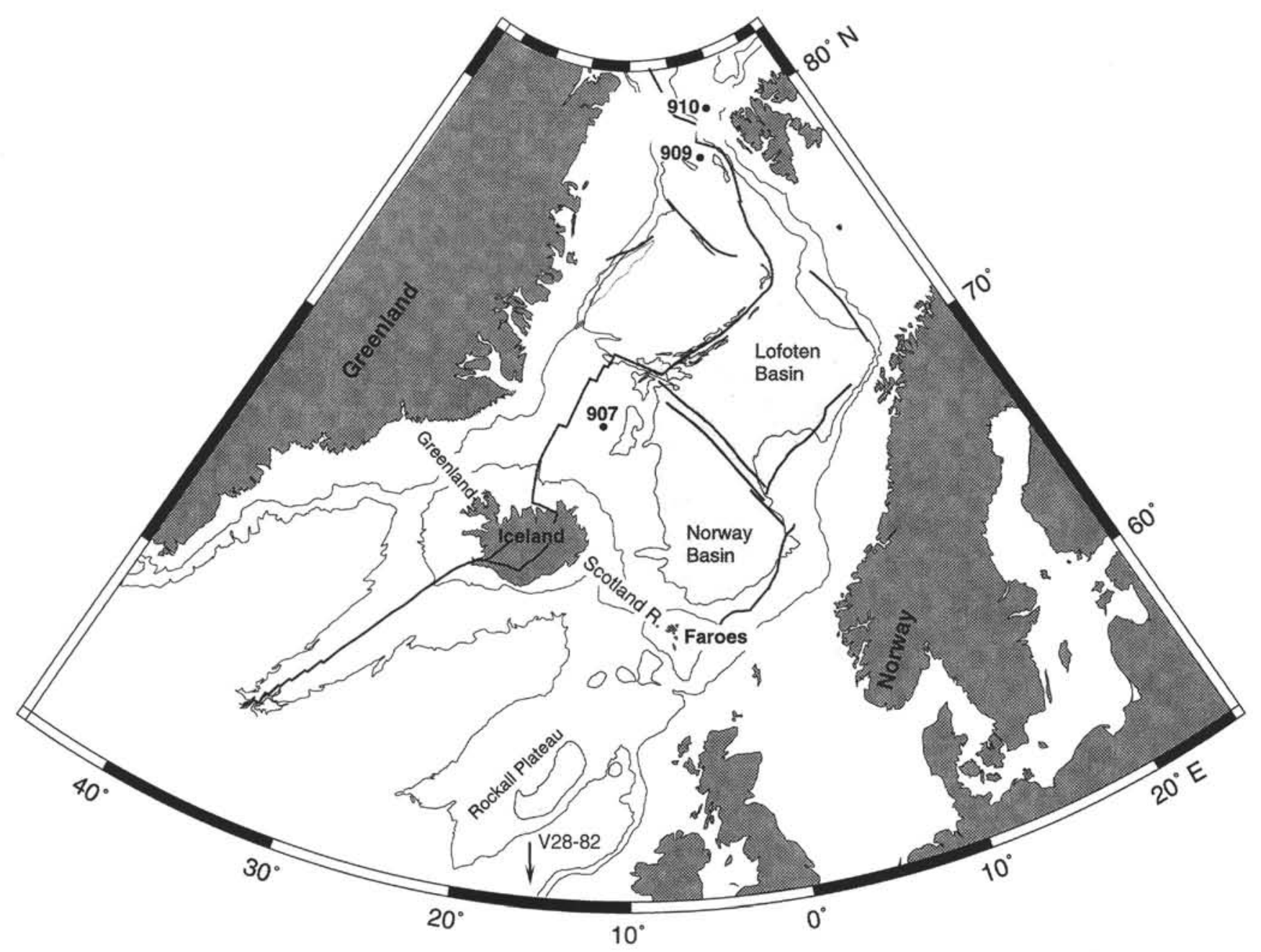

Figure 1. Map of the North Atlantic-Arctic Gateways. Site 907 was drilled on the Iceland Plateau, Site 909 in the Fram Strait, and Site 910 on the Yermak Plateau. V28-82 is a piston core recovered from $3935 \mathrm{~m}$ water depth in the eastern North Atlantic Ocean $\left(49.4^{\circ} \mathrm{N}, 22.3^{\circ} \mathrm{W}\right)$.

\section{RESULTS}

At Hole $907 \mathrm{~A}$, the MIS $5 / 6$ boundary occurs at $2.2 \mathrm{mbsf}$, and the mean sedimentation rate is thus $1.7 \mathrm{~cm} / \mathrm{k}$.y. The uppermost 20 centimeters of the core is characterized by isotopic values $<4.0 \%$ (Fronval and Jansen, this volume), indicating the Holocene, or MIS 1 (Fig. 2). This interval contains abundant planktonic foraminifers and relatively few coarse detrital grains. Subpolar foraminifers increase in abundance, as do benthic foraminifers. Beneath these youngest sediments is a layer containing a disseminated rhyolitic ash, consisting of clear, platy, bubble-wall shards (Fig. 3). We conclude that this layer represents a portion of Ash Zone 1 (Bramlette and Bradley, 1941; Ruddiman and Glover, 1972) dated by ${ }^{14} \mathrm{C}$ to $10,000-11,000$ years (Mangerud et al., 1984; Bard et al., 1994). The peak in shard concentration at $0.22 \mathrm{mbsf}$ in Hole $907 \mathrm{~A}$ indicates that the youngest sediments were largely recovered at this site, and, since there is little sediment missing at the core top, the estimated sedimentation rate need not be adjusted.

Beneath the upper $20 \mathrm{~cm}$, both the abundance and diversity of planktonic foraminifers diminish (Fig. 3). Concentrations decrease by an order of magnitude, and the faunal assemblage becomes nearly monospecific, consisting of more than $95 \%$ Neogloboquadrina pachyderma sinistral. Beneath $1.0 \mathrm{mbsf}$ there is a slight increase in faunal concentration, and beneath $1.8 \mathrm{mbsf}$, the faunal concentra- tions, subpolar species abundance, and isotopic values exceed those at the core top. Although the concentration of lithic fragments varies throughout, it remains generally high down to $1.8 \mathrm{mbsf}$ and drops to a minimum below that level. Beneath $2.1 \mathrm{mbsf}$, all of the indicators follow a similar pattern as beneath 0.2 mbsf. The proportion of icerafted to biogenic particles in the coarse fraction also varies throughout, with prominent peaks evident in MIS 2-4 and at each of the deglacial transitions.

At Hole $909 \mathrm{~A}$ the $>63-\mu \mathrm{m}$ fraction varies from less than $5 \%$ of the total sediment weight to peaks greater than $20 \%$ within the upper 4.4 mbsf (Fig. 2). Below this horizon, the values increase to more than $30 \%$ before diminishing again below $5.0 \mathrm{mbsf}$. These variations correlate with those of a nearby core, 21535-3, which has a published oxygen isotope stratigraphy (Kohler and Spielhagen, 1990). A distinct lithologic change marks the MIS 5/6 boundary, and indicates a mean sedimentation rate of $3.4 \mathrm{~cm} / \mathrm{k} . \mathrm{y}$. for the overlying sediments. Because the uppermost sediment is not clearly diagnostic of complete Holocene recovery, this rate must be considered a minimum value.

The planktonic foraminifer assemblage remains nearly monospecific at all depths, and the total abundances vary from zero to several thousand/gram (Fig. 4). Lithic concentrations vary throughout, with minima of less than $1000 / \mathrm{g}$ and maxima of greater than $3000 / \mathrm{g}$ down to $4.4 \mathrm{mbsf}$. Below this horizon lithic concentrations increase to more than $10,000 / \mathrm{g}$ before diminishing again. Coarse rock fragments are 
ODP 907A ODP 909A ODP 910A

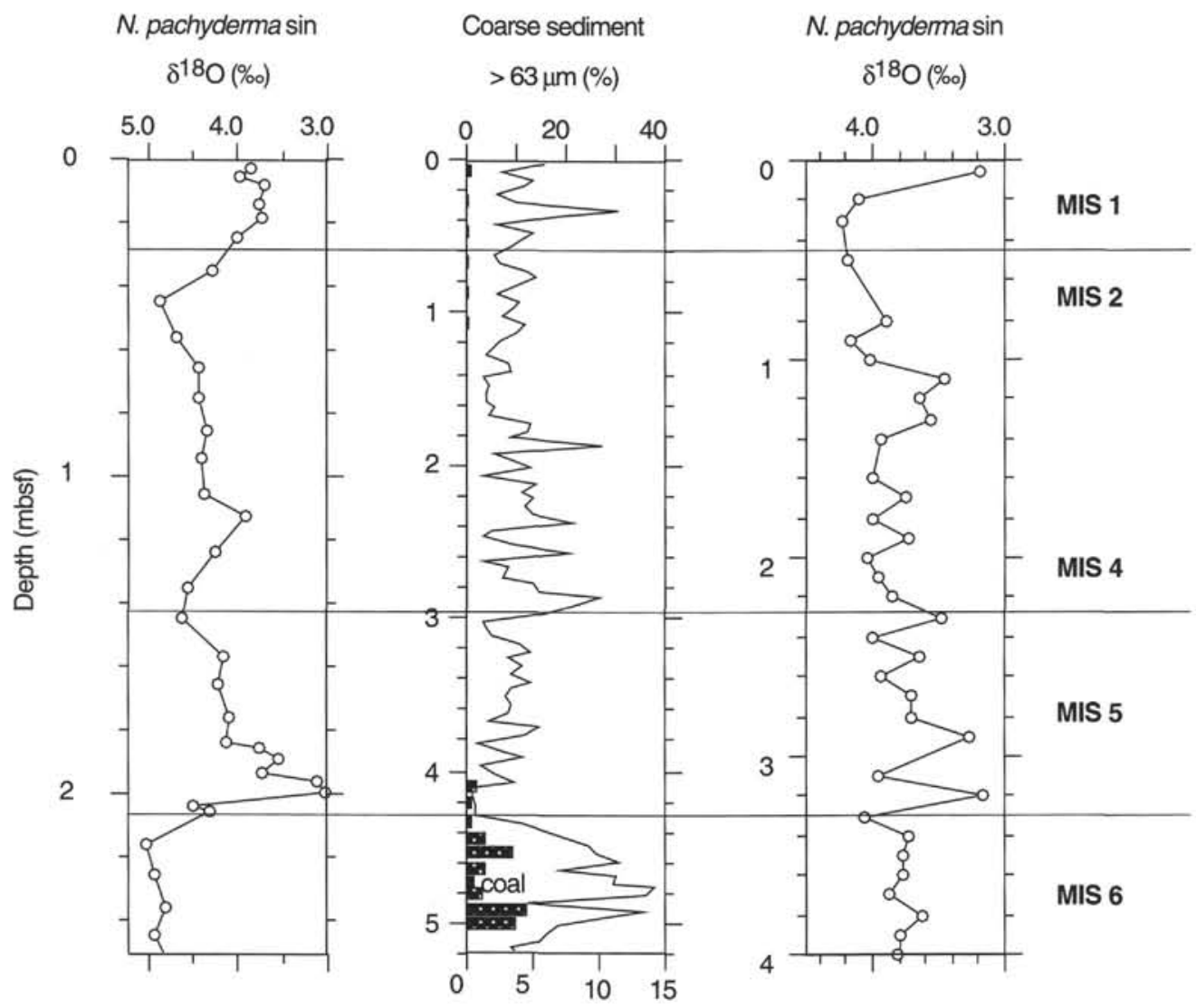

Figure 2. Stratigraphic summary of Sites 907,909 , and 910 . The plotted sections represent approximately 150,000 years. Planktonic oxygen isotopes from $N$. pachyderma sinistral were used at Sites 907 (Fronval and Jansen, this volume) and 910 (Flower, this volume). Stage boundaries were identified for three large isotopic transitions between marine isotope Stages $1 / 2,4 / 5$, and 5/6. The MIS 5/6 boundary was assigned an age of 130,000 years (Martinson et al., 1987). MIS 3 may be evident in moderately light values between MIS 2 and MIS 4 in both cores. Site 909 was correlated to a nearby gravity core (21535-3) on the basis of distinctive features in the record of coarse sediment, using weight percentage as a measure. Stage boundaries were then assigned based on the oxygen isotope stratigraphy of that core (Kohler and Spielhagen, 1990).

abundant, and the concentrations of specific rock types (i.e., siltstones and coal) vary from negligible to over $300 / \mathrm{gm}$. Coal fragments are particularly common below 4.4 mbsf, supporting the proposed stratigraphy, as such an increase was previously observed in MIS 6 (Bischof et al., 1990; Kohler and Spielhagen, 1990).

At Site 910 , the MIS 5/6 boundary occurs at $3.3 \mathrm{mbsf}$, and the mean sedimentation rate is thus $2.6 \mathrm{~cm} / \mathrm{k} . \mathrm{y}$. Isotopic values reach $3.2 \%$ in the uppermost interval (Flower, this volume), indicating the Holocene (Fig. 2). Unlike at Site 907, planktonic foraminifers remain rare in this and relatively few coarse detrital grains (Fig. 5). The oxygen isotope record increases to peak glacial values of over $4.2 \%$ o within the upper $1.0 \mathrm{mbsf}$, diminishes to intermediate values for 2 meters, and then drops to values near $3.2 \%$ again below 3.0 mbsf. This latter interval represents MIS 5, and is bounded by isotopic maxima that represent MIS 4 and MIS 6 . The mean sedimentation rate above this lower horizon is $2.7 \mathrm{~cm} / \mathrm{k}$.y. Again, because the uppermost sediment is not diagnostic of complete Holocene recovery, this rate is a minimum estimate.

Planktonic foraminifers occur only in minor concentrations and a nearly monospecific assemblage, dominated by Neogloboquadrina pachyderma sinistral, throughout the upper 5 meters (Fig. 5). Lithic concentrations remain consistently high within this interval, and reach peak values from 0.4 to $0.6 \mathrm{mbsf}$. Although coal fragments are present throughout, they rarely constitute as much as $2 \%$ of all coarse grains. Siltstone fragments are somewhat more abundant, varying from $2 \%$ to $6 \%$ below $1 \mathrm{mbsf}$, and rising to a single peak of more than $30 \%$ within the uppermost $0.5 \mathrm{mbsf}$.

\section{DISCUSSION}

Based on coarse fraction sedimentary components, the transect from Site 907 to Site 910 indicates a gradient of surface conditions at times during the last climate cycle. That gradient apparently diminished during the most severe and increased during the mildest intervals, as the northernmost site (Yermak Plateau) displays little faunal or IRD variability, while the southernmost site (Iceland Plateau) experienced significant climate amelioration during interglacials. These observations may be put in context by evaluating each proxy in turn. They may also be considered as part of an extended transect for comparison with evidence from the subpolar North Atlantic. There, climate variability is evident not only on glacial/interglacial time scales (e.g., Ruddiman and McIntyre, 1976) but also on millennial time scales in records of faunal assemblage (Bond et al., 1993) and IRD (Heinrich, 1988).

Each of the paleoceanographic proxies utilized in these previous studies, and in our own, measures the relative importance of some sensitive indicator. In the case of faunal assemblages it is the relative 


\section{ODP $907 A$}

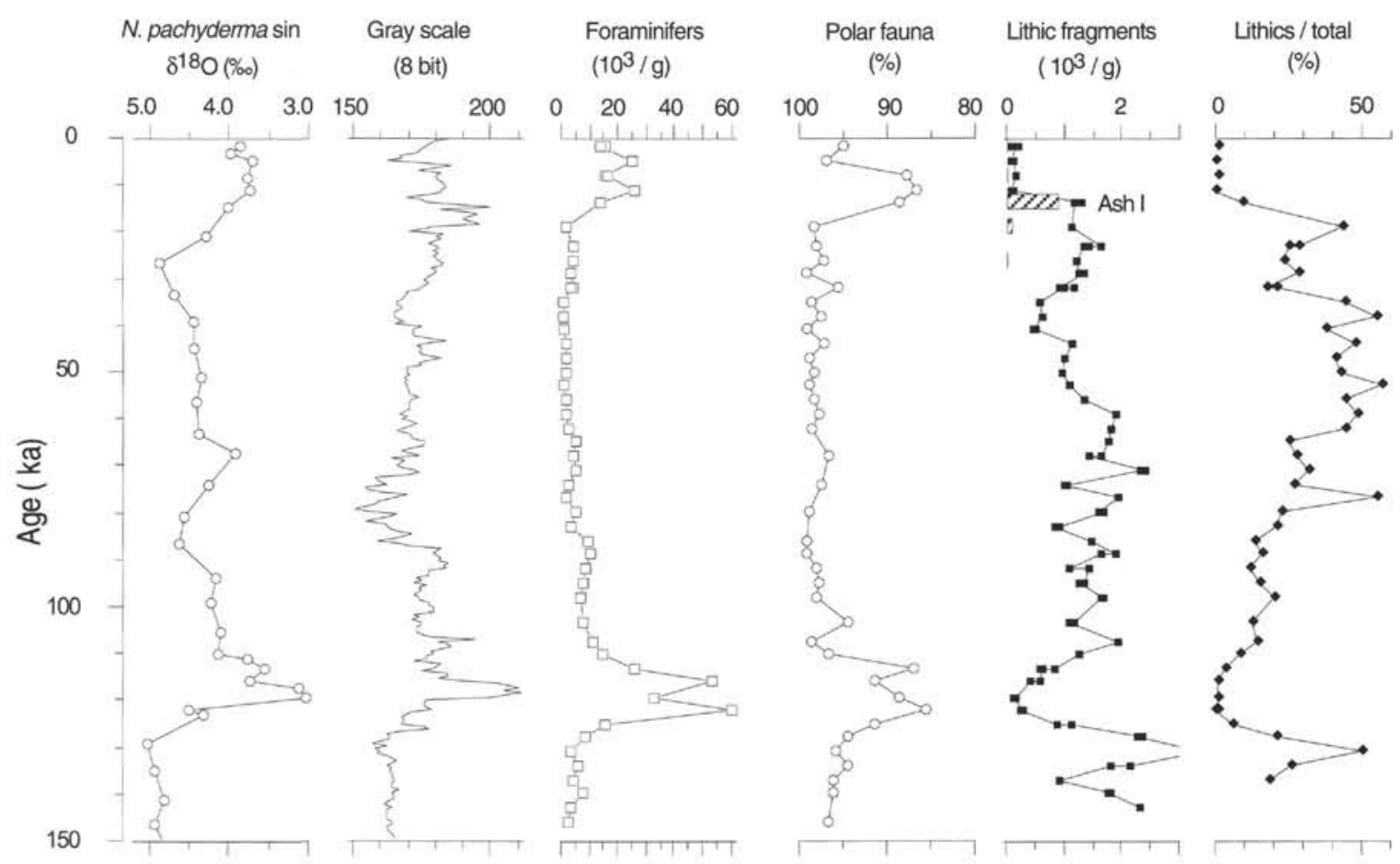

Figure 3. Time series from Site 907. Oxygen isotopes were measured on $N$. pachyderma sinistral. Gray scale values are based on the relative intensity of sediment reflectance from digitized core images. Foraminifer abundances are based on counts of all specimens in a sample split several times, multiplied by the number of times split, and divided by the dry bulk mass of sediment collected at a given depth. Polar fauna values were generated by identifying and counting N. pachyderma sinistral specimens as a percentage of all planktonic foraminifers (approximately 300) in a given split sample. Lithic fragment concentrations were calculated counting detrital grains using the same procedure as stated for foraminifer abundances. The number of lithics counted to the total of lithics and foraminifers counted in the same aliquot was multiplied by 100 to yield a percentage. This parameter is equivalent to the percentage IRD (Heinrich, 1988) or IRD grain percentage (Baumann et al., 1995) used by others.

abundance of polar forms, in the case of lithic concentrations it is the importance of ice-rafting relative to other sedimentary processes, and in the IRD grain ratio it is the importance of ice-rafting relative to foraminifer productivity and preservation. Changes in these proxies, in turn, may imply changes at the sea surface such as temperature and productivity, the degree of glaciation on surrounding land masses, and circulation patterns by way of iceberg trajectories. Each proxy is sensitive to a range of variation, and becomes insensitive at both extremes, when it remains at minimum or maximum levels. In these extreme cases the proxy signal may be considered saturated, and other proxies having different ranges of response must be considered.

On the Iceland Plateau, due to polar foraminifer abundances near saturation $(100 \%)$ for much of the record, faunal variation is limited to glacial/interglacial contrasts. The millennial-scale faunal variability in the North Atlantic (e.g., Bond et al., 1993) is not apparent at Site 907. At Sites 909 and 910 even the glacial/interglacial signal is diminished. One unlikely possibility is that these sites experienced long intervals of stable climate between peak interglacials. A more likely explanation is evident in the records of ice-rafting. At the time within MIS 5 that polar foraminifer abundances returned to values above $95 \%$ at Site 907 , IRD increased in importance. The concentration of lithic fragments then varied by a factor of two to four throughout the ensuing glaciation before returning to negligible values in the Holocene. At Site 909 a similar pattern of variability in IRD continues throughout the recovered record. The measured lithic concentrations at these two sites imply variable iceberg delivery. This variability may reflect glacial growth and retreat on nearby land masses, and it may also be influenced by the sensitivity of iceberg melting to small changes in sea surface temperature (Hebbeln and Wefer, 1991). In either case, faunal assemblages do not capture the same variability. At Site 910 , the concentration of lithic fragments remained at very high values at all times. Again, this may reflect stable conditions on the Yermak Plateau, although it more likely indicates that ice-rafting is so important at all times that the IRD proxy is effectively saturated. Part of the rationale for examining the siltstone rock fragments at our northern sites was to consider a possibly more sensitive proxy during intervals when ice-rafting was uniformly high. While these fragments did vary in abundance at Site 909, they remained low at Site 910. The increase in siltstones at Site 909 indicates the increased relative importance at that location of IRD from a sedimentary source. The increase in lithic concentrations at the same times indicates that the total ice-rafting increased, and that the relative change in IRD composition was not solely due to the diminution of a previously important source. Clastic rock fragments may have been delivered to the Fram Strait by ice streams extending down the western fjords of Spitsbergen from the sedimentary interior basins (Birkenmayer, 1981). As pointed out by Bischof (1994), they may also have come from a number of other sources, including southern portions of the Barents ice sheet. Additional analyses may be required to pinpoint this variable source, although we can say that the influence does not appear to extend to the Yermak Plateau. Variability at Site 910 may yet be evident in measurements of integrated mass fluxes using improved oxygen isotope age control, estimates of instantaneous mass fluxes using excess ${ }^{230} \mathrm{Th}$, or in more comprehensive petrologic (Bis- 


\section{ODP 909A}
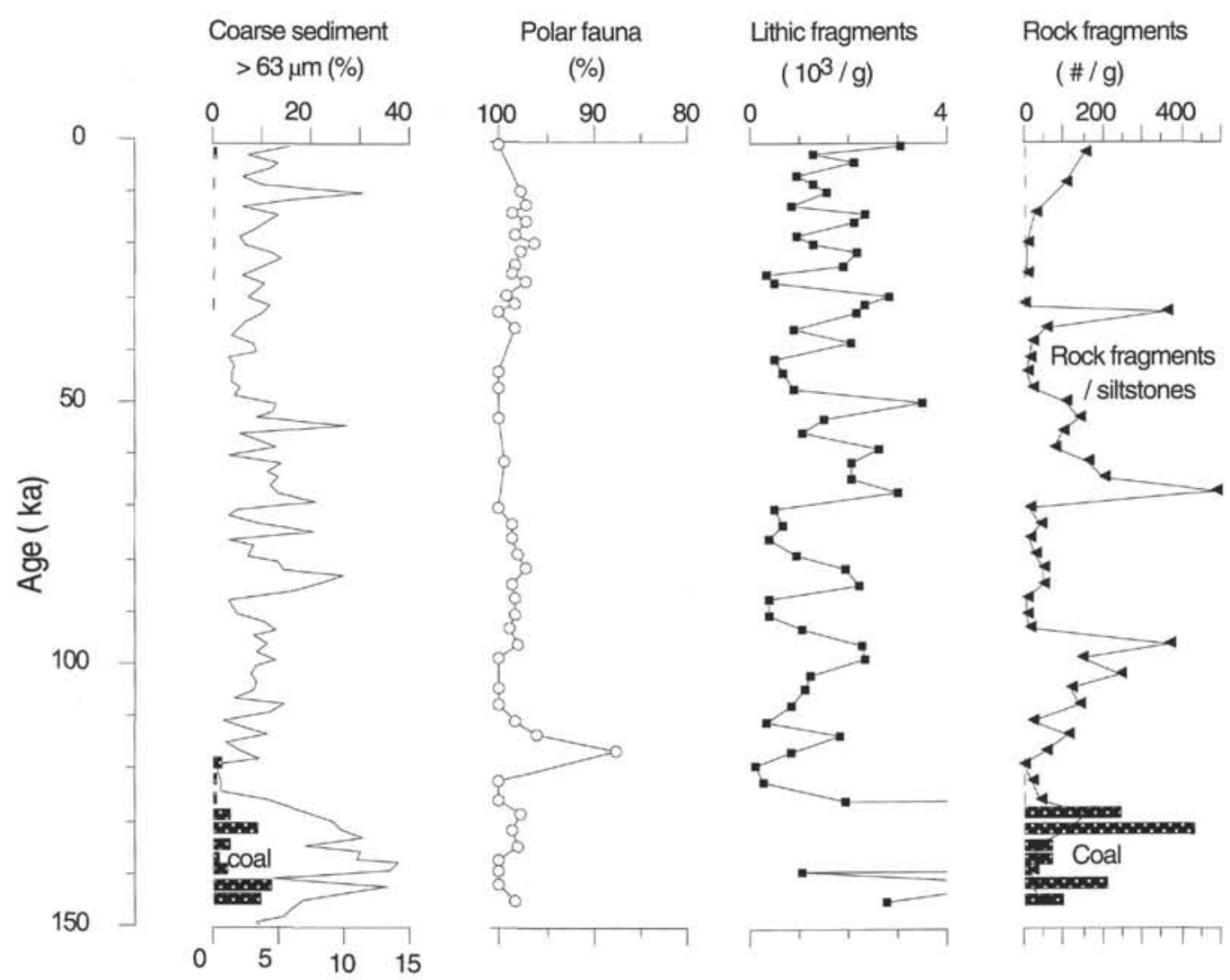

Figure 4. Time series from Site 909. Coarse fraction weight percentage was calculated by weighing the dry bulk sample, weighing the fraction captured in a 63 $\mu \mathrm{m}$ sieve, dividing the two weights, and multiplying by 100 . Polar fauna values were generated by identifying and counting $N$. pachyderma sinistral specimens as a percentage of all planktonic foraminifers (approximately 300) in a given split sample. Lithic fragment concentrations were calculated using the counted value of all detrital grains in a split sample, multiplied by the number of times split, and divided by the dry bulk mass of sediment collected at a given depth. Coal and siltstone rock fragment abundances were calculated using the same procedure as stated for lithic fragment abundances.

chof, 1994; Bond and Lotti, 1995) and isotopic (Grousset et al., 1993; Gwiazda et al., in press) tracers of detrital provenance.

While IRD abundance does not vary at Site 910, both Holes 907A and 909A display a pattern of variable ice-rafting that began following a minimum early in MIS 5 . It is not possible to date the IRD increases precisely, yet it is clear that there are more cycles than might be explained by orbital forcing. It is tempting to view this severalthousand-year variability in the light of high-frequency oxygen isotopic changes in deep ice cores from Greenland (Dansgaard et al., 1993). If those isotopic changes represent temperature shifts related to global, or at least regional, climate, they should also be evident in high quality records of the sea surface. There is increasing evidence that this is precisely the case in the North Atlantic (e.g., Bond et al., 1993; McManus et al., 1994; Bond and Lotti, 1995), and in the Nordic Seas (Larsen et al., 1995; Fronval et al., 1995; Stein et al., in press). This latter group of studies is now supported by the evidence from Sites 907 and 909 . One consequence of this variability in particular in the Gateways region is its communication outside the region by way of global circulation. Sub-Milankovitch changes in deep-water chemistry during MIS 5 appear to support such a link (Keigwin et al., 1994).

The ratio of lithic fragments to foraminifers is an index of ice-rafting when foraminifer deposition and preservation is constant. In practice, even in high preservation locations, this ratio reflects a more complex interaction of ice-rafting and foraminifer productivity. A series of events that punctuated the last glaciation (Heinrich, 1988) is characterized by discrete peaks in this ratio during MIS $2-4$ and again in late MIS 6 in the subpolar North Atlantic. North of $50^{\circ} \mathrm{N}$ this distinct signal wanes (Bond et al., 1992; Grousset et al., 1993; Robinson et al., 1995) as fewer icebergs survived the generally southwestnortheast transit. Consequently, the signal at Site 907 cannot be due to the arrival of the same iceberg armada, but must reflect deposition of locally derived IRD. This finding, together with similar evidence from the Norwegian Sea (Baumann et al., 1995), Greenland Sea (Stein et al., in press), and North Atlantic (Bond and Lotti, 1995) supports the idea that climatically driven advances of multiple ice sheets, rather than Laurentide ice dynamics (MacAyeal, 1993), were responsible for the Heinrich events. The similar pattern of peaks in records from the eastern North Atlantic and the Iceland sea (Fig. 6) may reflect a similar combination of relatively distal sites and sensitivity to possible influences on foraminifer productivity, such as colder temperatures and meltwater.

Although four MIS 5 events were postulated by Heinrich (1988), and subsequently identified (McManus et al., 1994), they were not of sufficient scale to overwhelm foraminifer deposition. Only at the transition from MIS 6 and during the major glaciation subsequent to 


\section{ODP 910A}
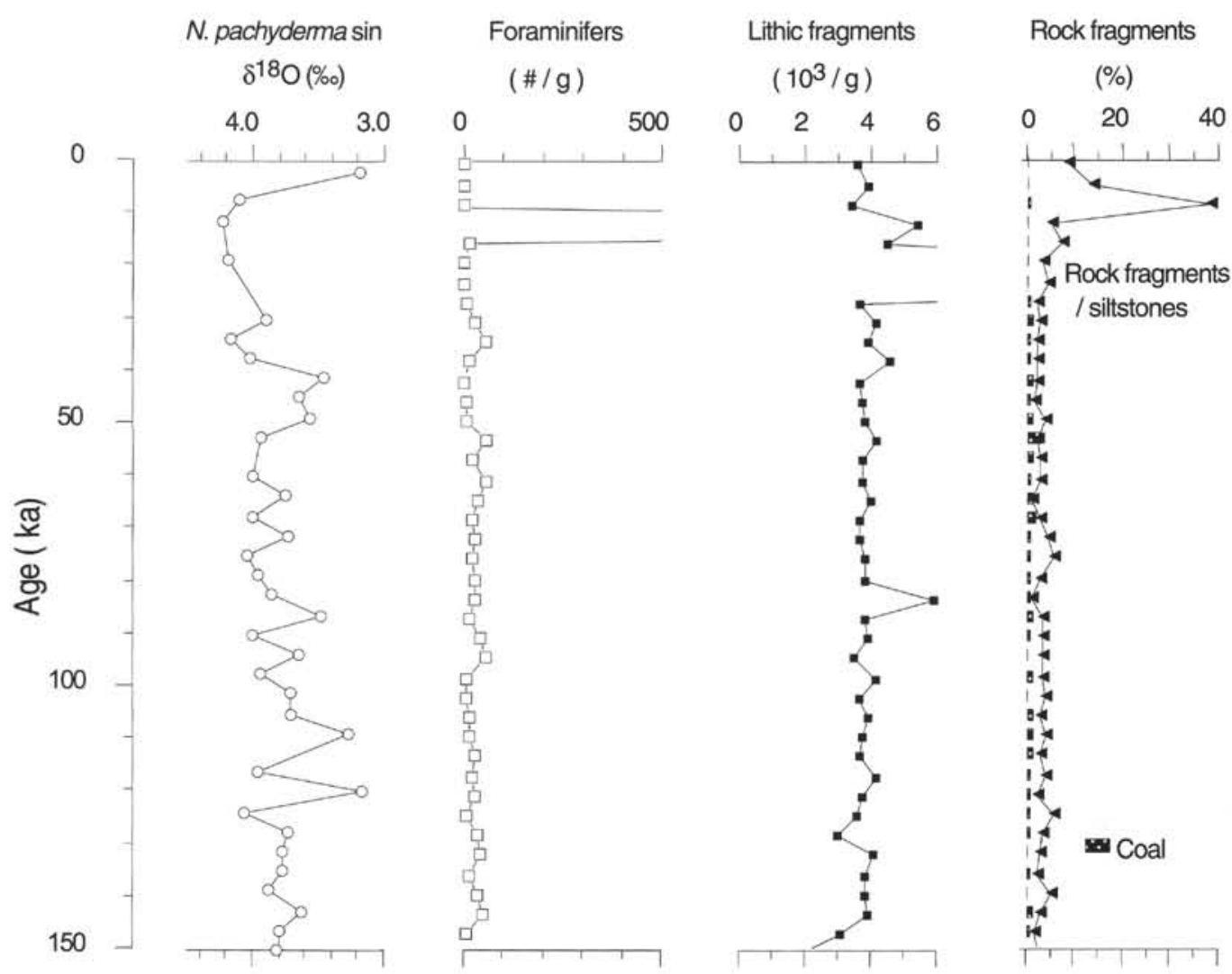

Figure 5. Time series from Site 910. Oxygen isotopes were measured on N. pachyderma sinistral. Foraminifer abundances are based on counts of all specimens in a sample split several times, multiplied by the number of times split, and divided by the dry bulk mass of sediment collected at a given depth. Polar fauna values are not plotted, as foraminifer abundances on the order of units to tens per gram were insufficient to provide statistical confidence in assemblage estimates. Lithic fragment concentrations were calculated by taking the counted value of all detrital grains in a split sample, multiplied by the number of times split, and divided by the dry bulk mass of sediment collected at a given depth. Coal and siltstone rock fragment abundances were calculated using the same procedure as stated for lithic fragment abundances, then divided by the total lithic abundance and multiplied by 100 .

MIS 5 did full scale Heinrich events occur. Large ice sheets, upon reaching a threshold at the MIS $4 / 5$ transition, apparently played a role in amplifying a signal that was present prior to the end of MIS 5.

Because Quaternary climate is largely cyclical in nature, it is often possible to consider long time series as the record of repeated glacial and interglacial episodes and the transitions between them. For this reason this study might be expected to provide insights into what might be considered the typical prevailing conditions at each site during climatic extremes. Only at Hole $907 \mathrm{~A}$ is this true, in that the glacial/interglacial pairs MIS 5/6 and MIS $1 / 2$ were similar to each other with respect to faunal and IRD content. At the other sites, while individual time series returned to similar values, in no case was the broad suite of proxies repeated, either during peak glacials or interglacials. Whereas the interglacial aspect of this observation might be attributed to the "anomalous" character of MIS 5 (Kohler and Spielhagen, 1990), the dissimilarity between glacial MIS 2 and MIS 6 is as great or greater at Hole 909A. This implies that multiple glacial influences and local overprints may rival or alter the glacial/interglacial signal sufficiently that caution is justified in paleo-interpretations.

\section{CONCLUSIONS}

The last climatic cycle was largely, if not completely, recovered at the three Leg 151 sites we examined. Sub-Milankovitch variability is evident in ice-rafting cycles on the Iceland Plateau and in the Fram Strait. The composition of IRD varied to a greater extent at Site 909 than at Site 910, implying a variability in the influence of surrounding ice sheets, surface trajectories, or thermal gradients. The last two glacial/interglacial pairs were dissimilar at two of the three sites, complicating the interpretation of earlier conditions.

\section{REFERENCES}

Bard, E., Arnold, M., Mangerud, J., Paterne, M., Labeyrie, L., Duprat, J., Melieres, M.-A., Sonstegaard, E., and Duplessy, J.-C., 1994. The North Atlantic atmosphere-sea surface ${ }^{14} \mathrm{C}$ gradient during the Younger Dryas climatic event. Earth Planet. Sci. Lett., 126:275-287.

Baumann, K.-H., Lackschewitz, K.S., Mangerud, J., Spielhagen, R.F., WolfWelling, T.C.W., Henrich, R., and Kassens, H., 1995. Reflection of Scandinavian ice sheet fluctuations in Norwegian Sea sediments during the past 150,000 years. Quat. Res., 43:185-197.

Birkenmayer, K., 1981. The geology of Svalbard, the western part of the Barents Sea and the continental margin of Scandinavia. In Nairn, A.E.M., Churkin, M., and Stehli, F.G. (Eds.), The Ocean Basins and Margins (Vol. 5): The Arctic Ocean: New York (Plenum), 265-329.

Bischof, J., 1990. Dropstones in the Norwegian-Greenland Sea: indications of Late Quaternary circulation patterns? In Bleil, U., and Thiede, J. (Eds.), Geological History of the Polar Oceans: Arctic versus Antarctic. NATO ASI Ser. C, 308.

, 1994. The decay of the Barents ice sheet as documented in Nordic seas ice-rafted debris. Mar. Geol., 117:34-55. 
Bischof, J., Koch, J., Kubisch, M., Spielhagen, R.F., and Thiede, J., 1990. Nordic seas surface ice drift reconstructions: evidence from ice rafted coal fragments during oxygen isotope stage 6. In Dowdesdwell, J.A., and Scourse, J.D. (Eds.), Glacimarine Environments: Processes and Sediments. Geol. Soc. Spec. Publ. London, 53:235-251.

Bond, G., Heinrich, H., Broecker, W., Labeyrie, L., McManus, J., Andrews, J., Huon, S., Janitschik, R., Clasen, S., Simet, C., Tedesco, K., Klas, M., Bonani, G., and Ivy, S., 1992. Evidence for massive discharge of icebergs into the North Atlantic ocean during the last glacial period. Nature, 360:245-249.

Bond, G.C., Broecker, W.S., Johnsen, S., McManus, J.F., Labeyrie, L., and Jouzel, J., 1993. Correlation between climate records from North Atlantic deep-sea sediments and Greenland ice. Nature, 364:218-220.

Bond, G.C., and Lotti, R., 1995. Iceberg discharges into the North Atlantic on millennial time scales during the last glaciation. Science, 276:10051010.

Bramlette, M.N., and Bradley, W.H., 1941. Lithology and geologic interpretations (Part 1). In Bradley, W.H. (Ed.), Geology and Biology of North Atlantic Deep Sea Cores Between Newfoundland and Ireland. Geol. Surv. Prof. Pap. U.S., 1-134.

Dansgaard, W., Johnsen, S., Clausen, H.B., and Langway, C.C., 1971. Climatic record revealed by the Camp Century Ice core. In Turekian, K.K. (Ed.), The Late Cenozoic Ice Ages: New Haven (Yale Univ. Press), 3756.

Dansgaard, W., Johnsen, S.J., Clausen, H.B., Dahl-Jensen, D., Gundestrup, N.S., Hammer, C.U., Hvidberg, C.S., Steffensen, J.P., Sveinbjörnsdottir, A.E., Jouzel, J., and Bond, G., 1993. Evidence for general instability of past climate from a 250-kyr ice-core record. Nature, 364:218-220.

Fronval, T., Jansen, E., Bloemendal, J., and Johnsen, S., 1995. Oceanic evidence for coherent fluctuations in Fennoscandian and Laurentide ice sheets on millennium timescales. Nature, 374:443-446.

Grousset, F.E., Labeyrie, L., Sinko, J.A., Cremer, M., Bond, G., Duprat, J., Cortijo, E., and Huon, S., 1993. Patterns of ice-rafted detritus in the glacial North Atlantic $\left(40^{\circ}-55^{\circ} \mathrm{N}\right)$. Paleoceanography, 8:175-192.

Gwiazda, R.H., Hemming, S., and Broecker, W.S., in press. Tracking the sources of icebergs with lead isotopes: the provenance of ice-rafted debris in Heinrich layer 2. Paleoceanography.

Hays, J.D., Imbrie, J., and Shackleton, N.J., 1976. Variations in the Earth's orbit: pacemaker of the ice ages. Science, 194:1121-1132.

Hebbeln, D., and Wefer, G., 1991. Effects of ice coverage and ice-rafted material on sedimentation in the Fram Strait. Nature, 350:409-411.

Heinrich, H., 1988. Origin and consequences of cyclic ice rafting in the northeast Atlantic Ocean during the past 130,000 years. Quat. Res., 29:142-152.

Imbrie, J., Hays, J.D., Martinson, D.G., McIntyre, A., Mix, A.C., Morley, J.J., Pisias, N.G., Prell, W.L., and Shackleton, N.J., 1984. The orbital theory of Pleistocene climate: support from a revised chronology of the marine $\delta^{18} \mathrm{O}$ record. In Berger, A., Imbrie, J., Hays, J., Kukla, G., and Saltzman, B. (Eds.), Milankovitch and Climate (Pt. 1), NATO ASI Ser. C, Math Phys. Sci., 126: Dordrecht (D. Reidel), 269-305.

Keigwin, L.D., Curry, W.B., Lehman, S.J., and Johnsen, S., 1994. The role of the deep ocean in North Atlantic climate change between 70 and $130 \mathrm{kyr}$ ago. Nature, 371:323-326.
Kellogg, T.B., 1980. Paleoclimatology and paleo-oceanography of the Norwegian and Greenland seas: glacial-interglacial contrasts. Boreas, 9:115137.

Kohler, S.E.I., and Spielhagen, R.F., 1990. The enigma of oxygen isotope stage 5 in the central Fram Strait. In Bleil, U., and Thiede, J. (Ed.), Geological History of the Polar Oceans: Arctic versus Antarctic. NATO ASI Ser. C, 308:489-498.

Larsen, E., Sejrup, H.-P., Johnsen, S., and Knudsen, K.-L., 1995. Do Greenland ice cores reflect northwestern European interglacial climate variations? Quat. Res., 43:125-132.

MacAyeal, D., 1993. Binge/purge oscillations of the Laurentide ice sheet as a cause of the North Atlantic's Heinrich events. Paleoceanography, 8:775795.

Mangerud, J., Lie, S.E., Furnes, H., Kristiansen, I.L., and Lømø, L., 1984. A Younger Dryas ash bed in western Norway, and its possible correlations with tephras in cores from the Norwegian Sea and the North Atlantic. Quat. Res., 21:85-104.

Martinson, D.G., Pisias, N.G., Hays, J.D., Imbrie, J., Moore, T.C., Jr., and Shackleton, N.J., 1987. Age dating and the orbital theory of the ice ages: development of a high-resolution 0 to 300,000 -year chronostratigraphy. Quat. Res., 27:1-29.

McManus, J.F., Bond, G.C., Broecker, W.S., Johnsen, S., Labeyrie, L., and Higgins, S, 1994. High-resolution climate records from the North Atlantic during the last interglacial. Nature, 371:326-329.

Robinson, S.G., Maslin, M.A., and McCave, I.N., 1995. Magnetic susceptibility variations in late Pleistocene deep-sea sediments of the N. E. Atlantic: implications for ice-rafting and paleocirculation at the last Glacial Maximum. Paleoceanography, 10:221-250.

Ruddiman, W.F., 1977. Late Quaternary deposition of ice-rafted sand in the subpolar North Atlantic (Lat $40^{\circ} \mathrm{N}$ to $65^{\circ} \mathrm{N}$ ). Geol. Soc. Am. Bull., 88:1813-1827.

Ruddiman, W.F., and Glover, L.K., 1972. Vertical mixing of ice-rafted volcanic ash in North Atlantic sediments. Geol. Soc. Am. Bull., 83:2817-2835.

Ruddiman, W.F., and McIntyre, A., 1976. Northeast Atlantic paleoclimatic changes over the past 600,000 years. In Cline, R.M., and Hays, J.D. (Eds.), Investigation of Late Quaternary Paleoceanography and Paleoclimatology. Mem.-Geol. Soc. Am., 145:11-145.

Spielhagen, R.F., 1991. Die Eisdrift in der Framstrasse während der letzten 200,000 Jahre. GEOMAR Rep., 4.

Stein, R., Nam, S.-I., Grobe, H., and Hubberten, J., in press. Late Quaternary glacial history and short-term IRD fluctuations along the East Greenland Continental Margin. In Andrews, J., et al. (Eds.), Late Pleistocene North Atlantic Paleoceanography. Geol. Soc. Spec. Publ. London.

Date of initial receipt: 11 July 1995

Date of acceptance: 30 December 1995 Ms 151SR-131 


\section{ODP 907A V28-82}

Gray scale

(8 bit)
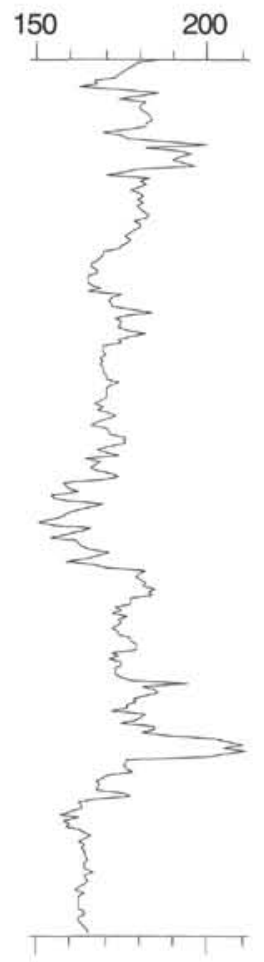

Gray scale

(8 bit)

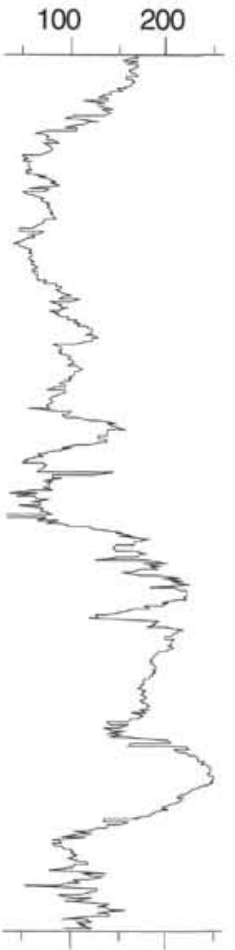

V28-82 ODP 907A

Lithics / total

$(\%)$

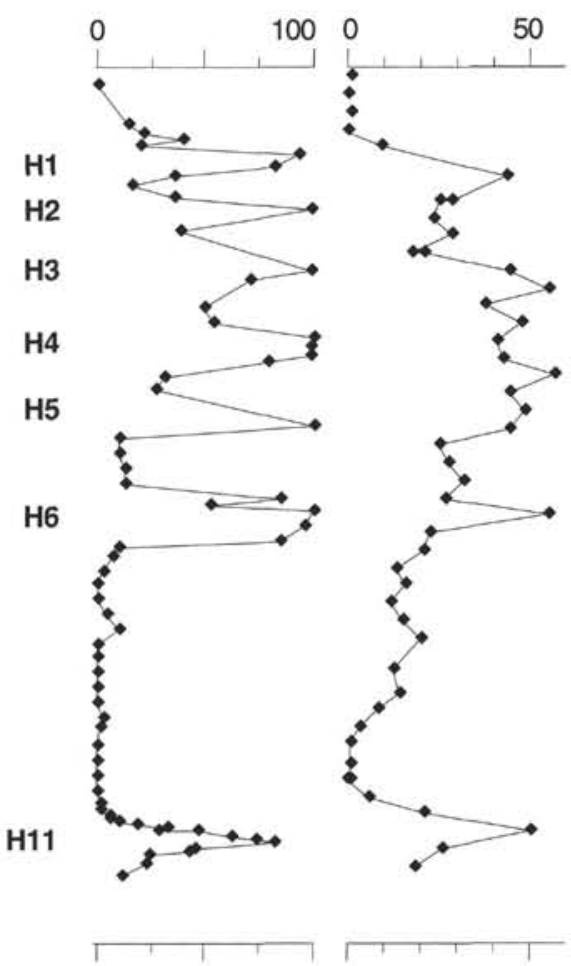

Figure 6. Time series of digitized image reflectance and lithic abundance relative to total entities $>150 \mu \mathrm{m}$. V28-82 is a piston core recovered from the eastern North Atlantic, well within the belt of maximum IRD deposition (Ruddiman, 1977). Gray scale values were generated from electronic scans of digitized core photographs. The sediment reflectance was divided into 256 relative levels, plotted here with high values indicating high reflectance of light sediment. The number of lithics counted to the total of lithics and foraminifers counted in the same aliquot was multiplied by 100 to yield a percentage. This parameter is equivalent to the percentage IRD (Heinrich, 1988) or IRD grain percentage (Baumann et al., 1995) used by others. Heinrich events H1-H6 occur as peaks in the lithics/total ratio within the dark sediment reflecting glacial MIS 2-4. No peaks occur in the light sediment of MIS 1 and MIS 5. A single event, H11, marks the transition from MIS 6 to MIS 5. 